\title{
STANDARISASI KOMPETENSI AHLI AKUNTANSI SEKTOR PUBLIK
}

\author{
Sopian $^{1)^{*}}$, Ria Dewi Ambarwati ${ }^{2)}$ \\ ${ }^{1,2,}$ Politeknik Keuangan Negara STAN \\ Sopian@pknstan.ac.id \\ Riadewi@pknstan.ac.id
}

\begin{abstract}
The developments of technology have influenced many professional fields of work including individuals who have public sector accounting education backgrounds. With a qualitative research methodology, the results of the study concluded that standardization of competencies are required by regulations. Two level of competences are medium level (Diploma III) and Bachelor / Applied Bachelor degrees. Qualifications for a 3 year-Diploma are able to master and implement the expertise of the public sector accounting standards with the rules base approach and expertise in using SAKTI Application. Qualifications for the Bachelor / Applied level, an inherent prerequisite is the ability to operate the SAKTI application, and able to implement the expertise of the public sector accounting standards with the principles base approach.
\end{abstract}

Keyword: Standardizations, Competences; Public Sector Accounting

\begin{abstract}
ABSTRAK
Perkembangan teknologi telah mempengaruhi banyak bidang profesi termasuk individu yang memiliki latar belakang pendidikan akuntansi sektor publik. Dengan pendekatan kualitatif, hasil penelitian menyimpulkan bahwa standarisasi kompetensi diwajibkan oleh regulasi dengan tingkat pengukuran untuk ahli akuntansi sektor publik dengan kualifikasi tingkat Ahli Madya dan Sarjana/Sarjana Terapan. Kompetensi untuk tingkat Ahli Madya mampu menguasai dan mengimplementasikan keahlian di bidang akuntansi sektor publik dengan pendekatan rules base dan optimalisasi pemanfaatan teknologi informasi dalam bentuk aplikasi Sistem Akuntansi Pemerintah Tingkat Instansi (SAKTI). Untuk tingkat Sarjana atau Sarjana Terapan, penguasaan kemampuan operasional Sistem Akuntasi Pemerintah Tingkat Instansi (SAKTI) merupakan prasyarat melekat dan mampu menguasai dan mengimplementasikan keahlian di bidang akuntansi sektor publik dengan pendekatan principles base.
\end{abstract}

Kata Kunci: Standarisasi; Kompetensi; Akuntansi Sektor Publik 


\section{PENDAHULUAN}

Salah satu tujuan negara Indonesia sebagaimana termaktub dalam pembukaan konstitusi adalah mencerdaskan kehidupan bangsa dan memajukan kesejahteraan umum. Untuk mencapai tujuan negara tersebut, konstitusi menyatakan bahwa pemerintah mengusahakan dan menyelenggarakan sistem pendidikan nasional untuk menjamin hak setiap warga negara memperoleh pendidikan yang layak dan memadai. Sistem pendidikan nasional dirancang untuk meningkatkan keimanan dan ketakwaan dalam rangka mewujudkan akhlak mulia. Sistem pendidikan nasional juga dirancang untuk menjamin pemerataan kesempatan pendidikan, peningkatan mutu untuk menghadapi tantangan perubahan kehidupan lokal, nasional, global dengan mengadopsi manajemen pendidikan yang bersifat relevan dan efisien (Kemendikbud, 2012).

Dalam pidato pertamanya sebagai presiden terpilih, pada tanggal 14 Juli 2019 di Sentul International Convention Center (SICC) Bogor, Presiden Joko Widodo menyampaikan lima visi Indonesia di bawah kepemimpinannya bersama Ma'ruf Amin, yakni fokus melanjutkan pembangunan infrastruktur, pengembangan sumber daya manusia (SDM) dengan menjamin kesehatan anak-anak sekolah dan meningkatkan kualitas pendidikan, investasi yang seluasluasnya dalam rangka membuka sebesarbesarnya lapangan pekerjaan, melanjutkan reformasi birokrasi dan struktural, dan menjamin penggunaan Anggaran Pendapatan dan Belanja Negara (APBN) yang fokus dan tepat sasaran (Yuliawati, 2019). Secara khusus dalam menjelaskan visi ketiga tentang pengembangan sumber daya manusia, Presiden menyebutkan peningkatan kualitas pendidikan dan pentingnya vocational school.

Sekolah vokasi merupakan pendidikan tinggi program diploma yang menyiapkan mahasiswa untuk pekerjaan dengan keahlian terapan tertentu. Jenjang Pendidikan vokasi dapat dikembangkan hingga program doktor terapan (Undang-Undang No 12 Tahun 2012 Tentang Pendidikan Tinggi, 2012). Hasil survey terhadap masyarakat terkait pendidikan vokasi menunjukkan bahwa disiplin ilmu yang paling banyak diminati dan perlu dikembangkan adalah ilmu ekonomi, manajemen, akuntansi, audit dan pajak (Wikansari, Sutjiatmo, \& Kurniawan, 2018). Dengan pendekatan model pendidikan vokasi yang memiliki kurikulum spesifik pada disiplin ilmu terapan, diharapkan generasi muda dapat memperoleh pengetahuan dan keterampilan pada bidang ilmu tertentu yang menjadi keinginannya (Young, 2011).

Perubahan kehidupan nasional dan global sangat dipengaruhi oleh kemajuan teknologi informasi. Perkembangan pesat teknologi informasi telah memberikan dampak positif terhadap disiplin ilmu akuntansi. Perkembangan teknologi informasi khususnya pada bidang sistem informasi akuntansi telah banyak mengubah cara kerja akuntan (Astutin, 2008). Banyak pekerjaan akuntan yang secara teknis telah digantikan oleh komputer. Sistem informasi akuntansi yang telah terkomputerisasi mampu menghasilkan informasi akuntansi secara cepat, tepat dan akurat. Para akuntan dapat berkonsentrasi pada pengembangan dan pengendalian sistem yang telah berjalan dan membantu manajemen dalam pengambilan keputusan. Teknologi informasi telah mempengaruhi displin ilmu akuntansi manajemen, akuntansi keuangan, auditing dan pendidikan akuntansi (Taufik, 2017). Teknologi informasi diharapkan mampu dirancang untuk memenuhi kebutuhan informasi perusahaan yang mencerminkan kondisi strategis dan visi manajemen puncak yang berpadu dengan struktur, gaya dan tujuan manajemen yang dikelola secara efektif untuk menghasilkan keunggulan kompetitif. Teknologi informasi memberikan informasi lebih dalam berbagai format dan bentuk baik secara teks, grafik, sounds yang menarik tidak hanya bentuk laporan keuangan dalam format dan pernyataan yang telah baku sesuai dengan standar akuntansi keuangan. Dalam disiplin ilmu audit, perkembangan teknologi informasi telah mampu meningkatkan produktivitas dalam menjalankan profesi audit dengan kertas kerja elektronik sebagai penyesuaian atas sistem kerja klien yang telah berbasis teknologi informasi. Dalam bidang pendidikan akuntansi diharapkan bahwa kurikulum pendidikan akuntansi dapat mengintegrasikan pembelajaran teknologi informasi secara menyeluruh dan utuh sehingga 
mahasiswa memiliki kesadaran akan tentang fungsi perekayasa sistem informasi yang mampu menghasilkan dan mendistribusikan informasi untuk kepentingan pengambilan keputusan.

Beberapa faktor menjadi bahan pertimbangan mahasiswa dalam mengambil sertifikasi kompetensi untuk akuntansi sektor komersil. Terdapat empat faktor yang mempengaruhi mahasiswa dalam mengambil keputusan untuk melakukan sertifikasi kompetensi (Kusumaningrum \& Kirowati, 2017). Pertama adalah materi uji kompetensi, akses lokasi uji kompetensi dan tingkat kejenuhan dan tekanan profesi akuntansi. Kedua adalah informasi tentang sertifikasi, persyaratan dan minat melakukan ujii kompetensi. Faktor ketiga adalah persepsi tentang profesi akuntansi yang memiliki tingkat kesejahteraan yang baik dan status sosial yang tinggi. Terakhir adalah informasi seputar profesi akuntansi, biaya sertifikasi dan profesi akuntansi yang memiliki kecenderungan tidak kreatif.

Salah satu profil mahasiswa lulusan akuntansi adalah di bidang akutansi sektor publik. Para mahasiswa yang berkecimpung di bidang akuntansi sektor publik akan berkaitan dengan instansi pemerintah dan pelayanan publik (Widarno, 2007). Materi akuntansi sektor publik berkaitan dengan penganggaran, pendapatan, belanja, pembukuan, perpajakan dan sistem pengadministrasian. Di sisi lain, telah terjadi perubahan sistem akuntansi di sektor publik dari sistem kas menjadi sistem akrual (Simanjuntak, 2005). Perubahan dari sistem kas menjadi sistem akrual mengacu pada praktek akutansi pemerintah di berbagai negara. Dengan sistem akuntansi akrual, maka pembaca laporan keuangan akutansi sektor publik dapat mengevaluasi kinerja, posisi keuangan dan arus kas dan kemampuan pemerintah untuk mendanai kegiatannya. Di sisi lain, pembaca laporan keuangan pemerintah juga dapat mengevaluasi efisiensi atas biaya dan kemampuan pemerintah dalam mengelola sumber daya yang dimiliki.

Penelitian ini membahas tentang bagaimana pentingnya standarisasi kompetensi ahli akuntansi sektor publik, mengkaji sejauhmana peraturan perundangan yang ada memberi mandat atas pelaksanaan standarisasi kompetensi ini, mendiskusikan hasil penelitian lapangan tentang pelaksanaan standarisasi kompetensi di beberapa perguruan tinggi, baik yang berbentuk vokasional atau akademis. Pada akhirnya penelitian ini juga berupaya melahirkan suatu model standarisasi kompetensi yang dapat diimplementasikan pada perguruan tinggi,

\section{KAJIAN LITERATUR}

\section{Pendidikan Berbasis Kompetensi}

Saat ini praktek dunia pendidikan dan pelatihan di Indonesia tengah bergeser kepada paradigma baru pendidikan dan pelatihan, yaitu pendidikan dan pelatihan berbasis kompetensi. Pergeseran paradigma ini tidak hanya berlaku pada pendidikan yang berjenis kejuruan, baik pada jenjang pendidikan menengah maupun pendidikan tinggi, tetapi juga pada pendidikan yang berjenis pendidikan umum. Salah satu wujud pergeseran ini adalah lahirnya istilah baru dalam dunia pendidikan kita yaitu kurikulum berbasis kompetensi (KBK) menggantikan model kurikulum lama berbasis pembelajaran.

Pendidikan dan pelatihan berbasis kompetensi lahir sebagai koreksi atas pendidikan tradisional yang dirasakan terlalu menekankan pada pembentukan individu dengan intelegensi (IQ) yang tinggi dan mengabaikan tujuan terbentuknya individu yang memiliki keterampilan yang sesuai dengan prospek dunia kerjanya. Sedikit atau banyak pergeseran paradigma ini dipicu oleh tulisan dari salah seorang psikolog Harvard, McClelland pada makalahnya yang berjudul "Testing for Competence Rather Than for 'Intelligence" (McClelland, 1973).

Pada tulisan tersebut, McClelland mempertanyakan praktek di Amerika Serikat saat itu yang sangat mengandalkan tes intelegensi dan kemampuan umum (aptitude) dalam menentukan kesuksesan belajar sesorang. Hasil tes yang dilaksanakan oleh suatu lembaga tes (ETS) saat itu memiliki kekuatan yang sangat besar dalam menentukan masa depan seorang siswa SMA, yaitu memberikan semacam stempel "layak (qualified)" atau 
"tidak layak (less qualified)" untuk menjadi mahasiswa perguruan tinggi. Dengan lugas McClelland mempertanyakan 'Why should intelligence and aptitude tests have all this power?"

Menurut McClelland, tes IQ dan tes aptitude tidak dapat memberikan prediksi yang tepat mengenai kinerja seseorang di tempat kerjanya. Tes-tes tersebut hanyalah sebagian dari beberapa alternatif untuk memberi masukan mengenai kinerja seseorang. Sebagai alternatif McClelland mengembangkan suatu metode lain yang dikenal sebagai behavioral event interview (BEI) untuk mengidentifikasi kompetensi seseorang. Metode ini kemudian dikembangkan oleh (Spencer, Jr \& Spencer, 1993) dalam bentuk job competence assessment (JCA).

Lebih lanjut (Sanberg, 2000) mengemukakan bahwa perubahan teknologi yang cepat dalam bidang-bidang seperti ekonomi mikro dan komunikasi bersamaan dengan pertumbuhan dalam industri berbasis layanan dan pengetahuan telah mengarah pada kebutuhan untuk pengembangan kompetensi yang berkelanjutan untuk kesuksesan kompetitif. Dengan demikian, dari perspektif manajerial, kebutuhan ini mengarah pada permintaan lebih lanjut untuk cara-cara efisien untuk mengelola pelatihan dan pengembangan personil dalam organisasi. Namun, untuk mengelola pelatihan dan pengembangan secara efisien, manajer perlu memahami apa yang merupakan kompetensi personil di tempat kerja. Tanpa pemahaman seperti itu, pengembangan kompetensi tidak dapat dikelola secara efektif dan, oleh karena itu, efektivitas dalam organisasi tidak dapat dicapai.

Saat ini, pendekatan dominan yang digunakan dalam manajemen untuk mengidentifikasi kompetensi terdiri dari pendekatan yang berorientasi pada pekerja (the worker-oriented), pada pekerjaan (the workoriented), dan multimethod-oriented. Pada pendekatan yang berorientasi pada pekerja, kompetensi terutama dilihat sebagai didasari oleh atribut yang dimiliki oleh pekerja, biasanya direpresentasikan sebagai pengetahuan, keterampilan, kemampuan (KSA) dan sifat-sifat pribadi yang diperlukan untuk kinerja kerja yang efektif. Sebagai contoh, pendekatan berorientasi pekerja yang umum digunakan adalah metode elemen pekerjaan (Veres et al., 1990 dalam Sandberg 2000). Pendekatan (Spencer, Jr \& Spencer, 1993) di atas termasuk dalam pendekatan kedua yaitu yang berorientasi pada pekerjaan, karena keduanya menyimpulkan bahwa kinerja yang unggul di tempat kerja biasanya merupakan hasil dari serangkaian kompetensi tertentu yang digabungkan dengan cara tertentu. Namun, pendekatan yang berorientasi pekerja telah dikritik karena menghasilkan deskripsi kompetensi yang terlalu umum dan abstrak. Sementara para ahli yang mendukung pendekatan multimethod juga menetapkan bahwa kompetensi dibatasi oleh seperangkat atribut tertentu. Yang membedakan pendekatan multimethod dari yang lain adalah pendekatan mereka lebih komprehensif, mereka berusaha memperbaiki kritik yang diajukan atas kedua pendekatan sebelumnya.

\section{Perbedaan Pendidikan Berbasis Kompetensi dengan Pendidikan Tradisional}

Sebagaimana telah disinggung sebelumnya, perbedaan utama dari paradigma pendidikan berbasis kompetensi (PBK) dengan pendidikan tradisional adalah pada basis pelaksanaan yang digunakan dalam pendidikan tersebut. Pada pendidikan tradisional, basis pelaksanaan yang digunakan adalah pembelajaran, sementara pada pendidikan berbasis kompetensi, basis pelaksanaannya adalah kompetensi.

Pada pendidikan tradisional, pelajar harus mempelajari materi --seperti ilmu pengetahuan alam, bahasa, dan matematika-- secara terjadwal selama jangka waktu satu tahun pembelajaran. Karena kemajuan belajar terhadap berbagai materi tersebut dihitung sesuai waktu yang dijadwalkan, maka pada setiap waktu tertentu guru harus menyelesaikan materi pelajaran sampai titik tertentu dari buku teks atau isi pelajaran tersebut. Meski para siswa tidak memiliki kecepatan belajar yang sama, mereka harus mencapai titik penyelesaian materi yang sama dengan guru mereka. Tes dilaksanakan secara periodik untuk memastikan siswa memahami konsep-konsep dan prinsipprinsip yang diajarkan. Nilai tes seringkali dibandingkan untuk menentukan peringkat keberhasilan belajar para siswa. 
Meski tetap mempertimbangkan berbagai tingkat kesuksesan yang telah dicapai dengan pendidikan berbasis tradisional selama ini, secara umum dapat dikatakan bahwa sistem tradisional ini merupakan sistem yang tidak efektif ketika tujuan pendidikan adalah untuk melatih seseorang menguasai tugas tertentu atau menguasai keterampilan (skill) yang berhubungan dengan pekerjaan. Sebagai contoh, misalkan untuk melatih seorang pilot disiapkan suatu paket pembelajaran selama tiga minggu. Apakah menghadiri seluruh sesi pembelajaran tersebut akan menjamin calon pilot dapat sukses menerbangkan pesawat? Tentu tidak. Atau sebaliknya, apakah jika calon pilot tidak menghadiri dua hari pembelajaran dari tiga minggu yang dijadwalkan akan berarti bahwa calon pilot tidak akan dapat menerbangkan pesawatnya? Juga tentu tidak. Ketidakpastian yang sama berlaku terhadap hasil dari pelaksanaan tes tertulis dari pembelajaran tersebut. Kegagalan atau keberhasilan dalam tes tertulis tersebut tidak menjamin kesuksesan atau kegagalan calon pilot dalam menerbangkan pesawatnya.

Perbedaan lain dari paradigma pendidikan tradisional dengan pendidikan berbasis kompetensi adalah sebagai berikut (Flecther, 2005):

1. Dari sisi konsep, pendidikan tradisional didasarkan pada konsep penilaian kemampuan atau prestasi pembelajaran, sementara pendidikan berbasis kompetensi didasarkan pada konsep penilaian kinerja aktual di tempat kerja.

2. Dari sisi landasan pendidikan, pendidikan tradisional dilandaskan pada kurikulum yang ditetapkan oleh pengajar atau lembaga, sementara pendidikan berbasis kompetensi dilandaskan pada standar eksplisit kinerja, baik yang dipersyaratkan oleh industri, atau yang dirumuskan secara khusus sebagai standar kinerja unggul.

3. Dari sisi penilaian, pada pendidikan tradisional penilaian dipersyaratkan sebagai bagian integral dari pembelajaran, sementara pada pendidikan berbasis kompetensi penilaian harus dipisahkan (independen) dari program pembelajaran.

4. Dari sisi bukti penilaian, pada pendidikan tradisional bukti penilaian adalah hasil tes, ditentukan dalam kurikulum dan merujuk norma penilaian, sementara pada pendidikan berbasis kompetensi bukti penilaian dikumpulkan dari kinerja aktual di tempat kerja dan merujuk pada kriteria atau validasi kriteria dan bersifat individual.

\section{Regulasi Standarisasi Kompetensi}

Kualifikasi kompetensi seorang yang telah menyelesaikan jenjang pendidikan perguruan tinggi telah diatur dalam pasal 29 Undang-Undang Nomor 12 tahun 2012 tentang Pendidikan Tinggi. Kerangka kualifikasi nasional merupakan penjenjangan capaian pembelajaran yang menyetarakan luaran bidang pendidikan formal, nonformal, informal, atau pengalaman kerja dalam rangka pengakuan kompetensi kerja sesuai dengan struktur pekerjaan diberbagai sektor. Kerangka kualifikasi nasional menjadi acuan pokok dalam penetapan kompetensi lulusan pendidikan akademik, pendidikan vokasi, dan pendidikan profesi.

Untuk mengimplementasikan kerangka kualifikasi nasional, pemerintah telah menerbitkan Peraturan Presiden No 18 Tahun 2012 tentang Kerangka Kualifikasi Nasional Indonesia (KKNI). Secara definisi, Kerangka Kualifikasi Nasional Indonesia, yang selanjutnya disingkat KKNI, adalah kerangka penjenjangan kualifikasi kompetensi yang dapat menyandingkan, menyetarakan, dan mengintegrasikan antara bidang pendidikan dan bidang pelatihan kerja serta pengalaman kerja dalam rangka pemberian pengakuan kompetensi kerja sesuai dengan struktur pekerjaan di berbagai sector.

Sebagai salah satu wujud pelaksanaan standarisasi kompetensi maka dapat dilakukan uji kompetensi. Sertifikasi merupakan implementasi pelaksanaan standarisasi kompetensi atas keahlian di bidang tertentu dari seseorang yang telah menempuh pendidikan tinggi sebagaimana diatur dalam pasal 44 dalam Peraturan Presiden dimaksud. Untuk pelaksanaan sertifikasi, perguruan tinggi dapat melakukan kerjasama dengan organisasi profesi, lembaga pelatihan atau lembaga sertifikasi yang telah memperoleh akreditasi.

Pelaksanaan teknis proses pengakuan kompetensi dalam bentuk sertifikasi diatur 
dalam Peraturan Menteri Pendidikan dan Kebudayaan No 83 Tahun 2013 tentang Sertifikasi Kompetensi. Pengakuan kompetensi kerja atas prestasi lulusan yang sesuai dengan keahlian dalam cabang ilmunya dan/atau memiliki prestasi di luar program studinya berhak memperoleh sertifikat kompetensi. Perguruan tinggi memiliki kewenangan untuk menerbitkan sertifikat kompetensi sesuai dengan disiplin ilmu yang dari kompetensi yang akan disertifikasi. Di sisi lain perguruan tinggi juga diminta untuk melakukan kerjasama dengan organisasi profesi, lembaga pelatihan atau lembaga sertifikasi sesuai dengan ketentuan yang berlaku.

Perkembangan yang dinamis terkait pengaturan tentang standarisasi kompetensi diatur dalam Peraturan Menteri Riset, Teknologi dan Pendidikan Tinggi nomor 44 Tahun 2015. Standar kompetensi lulusan merupakan kriteria minimal tentang kualifikasi kemampuan lulusan yang mencakup sikap, pengetahuan, dan keterampilan yang dinyatakan dalam rumusan capaian pembelajaran lulusan. Standar kompetensi lulusan dipergunakan sebagai acuan utama pengembangan standar isi pembelajaran, standar proses pembelajaran, standar penilaian pembelajaran, standar dosen dan tenaga kependidikan, standar sarana dan prasarana pembelajaran, standar pengelolaan pembelajaran, dan standar pembiayaan pembelajaran.

\section{METODE PENELITIAN}

\section{Jenis Penelitian}

Pendekatan penelitian yang diaplikasikan adalah kualitatif. Penelitian kualitatif digunakan untuk meneliti kondisi objek yang alamiah dimana peneliti sebagai instrumen kunci dengan mempergunakan triangulasi sebagai teknik pengumpulan data dan dianalisa secara induktif dengan hasil penelitian lebih menekankan pada pemahaman makna dan mengkonstruksi fenomena (Sugiyono, 2017). Triangulasi dilakukan baik atas informan, investigator, dan lokasi untuk memperkuat kredibilitas penelitian.

Triangulasi informan dicapai dengan mewawancara kepada beberapa institusi, baik perguruan tinggi, maupun non perguruan tinggi. Perguruan tinggi yang bersedia untuk mendiskusikan dan berbagi materi meliputi sekolah vokasi Universitas Gadjah Mada, Politeknik Negeri Bandung, Universitas Brawijaya dan Politeknik Negeri Malang. Institusi pemerintah yang dijadikan sumber informasi adalah Direktorat Jenderal Perbendaharaan (DJPb) dan Pusdiklat Anggaran dan Perbendaharaan. Triangulasi investigator dilakukan dengan membagi tugas wawancara kepada beberapa peneliti untuk target informan yang berbeda. Triangulasi lokasi dilakukan bersamaan dengan pemilihan perguruan tinggi, dilakukan tidak hanya pada perguruan tinggi yang sama di satu kota, tapi dari beberapa kota.

\section{Teknik Pengumpulan dan Analisa Data}

Sumber data utama dalam penelitian adalah data primer yang diperoleh dari hasil wawancara di beberapa lokasi objek penelitian. Beberapa perguruan tinggi yang terlibat langsung dalam proses sertifikasi kami jadikan purposive sampling. Sumber informasi yang bersedia memberikan data terdiri dari Sekolah Vokasi UGM, Politknik Negeri Bandung dan Direktorat Jenderal Perbendaharaan. Teknik analisa data yang dalam penelitian adalah penerapan model Miles and Huberman (Sugiyono, 2017). Degaan model Miles and Huberman sebagai alat analisis data maka tahap analisa data terdiri dari tahap data reduction, data display dan conclusion. Reduksi data merupakan proses merangkum, memilih hal-hal pokok, memfokuskan pada hal-hal penting sesuai tema dan polanya serta membuang yang tidak perlu. Penyajian data dilakukan meliputi deskripsi data dalam bentuk uraian atau narasi singkat, bagan, hubungan antar kategori, menafsirkan suatu fakta, gejala dan peristiwa yang berhasil diamati dan dikonfirmasi selama proses pengumpulan data di lapangan untuk memahami apa yang terjadi dan merencanakan kerja selanjutnya berdasarkan apa yang telah difahami tersebut.

\section{HASIL PENELITIAN \\ Urgensi Standarisasi Kompetensi}

Sebagaimana telah diuraikan, bahwa ketentuan kompetensi lulusan perguruan tinggi yang terstandar telah diatur dalam UU No 12 Tahun tentang Pendidikan Tinggi khususnya pada pasal 44 yang mengatur tentang sertifikasi kompetensi. Penjabaran lebih lanjut tentang 
kompetensi terstandar diatur dalam peraturan menteri riset dan pendidikan tinggi. Pengaturan sertifikasi kompetensi diatur lebih rinci dalam Peraturan Menteri Riset, Teknologi dan Pendidikan Tinggi nomor 59 Tahun 2018. Hal ini sejalan dengan pendapat informan yang menekankan pentingnya pengukuran kompetensi dalam bentuk sertifikasi, sebagaimana diungkapkan informan:

"Nah kalo di Indonesia kan apa-apa harus ada hitam di atas putihnya. Formalitasnya ada."

Proses standarisasi kompetensi merupakan bagian yang tidak terpisahkan dari proses penyusunan kurikulum. Selayaknya adalah proses standarisasi sesuai (matching) dengan profil lulusan yang ingin dihasilkan. Untuk itu, prosesnya dapat dimulai dengan penentuan profil lulusan dan ditetapkan matakuliah yang relevan sebagaimana yang diuraikan oleh informan.

'”... Profil lulusan, apa sih profil lulusan yang relevan dan mana ngak relevan, akhinya kita tetapkan ini dan ini karena setelah dianalisis seperti ini ya yang masih relevan. Lalu setelah dari profil lulusan barulah kami terjemahkan ke kurikulum, mata kuliahnya apa saja, kita harus meghilangkan ego sektoral masing-masing ini oh matakuliah ini penting tapi apa pentingnya sih, penting beneran ngak sih kira-kira, jangan-jangan tidak, kita analisis lagi deh dari profile lulusan'

Profile lulusan dari LSPP. Profile lulusan harus bisa apa-apa dari LSPP, terus kami konsultasi dengan LSPP dan LSPP dengan senang hati memberikan masukan karena bagaimanapun juga itu sinkron walaupun LSPP tidak mengharuskan wajib training ya.

Profile lulusan itu kan punya definisi. Jadi setiap kami membuat profil lulusan kami punya definisi. Definisinya itu dari LSPP dan bila perlu kami tambahkan karena relevansi masa depan kami tambahi dan mungkin tidak relevan kami pertahankan ngak ada salahnya untuk belajar itu, kami sifatnya menambahkan"

Dengan merujuk pada program studi (prodi) perbankan sebagai benchmarking, maka proses standarisasi mahasiswa program diploma
(Prodi) D IV yang mengambil fokus analis kredit digambarkan oleh informan sebagai berikut:

"Seorang analis kredit itu harus bisa $A B C D E$, dari sana itu bahkan saya bikin bagannya di naskah rancangan kurikulum, saya buat bagannya dengan jelas, skill yang dibutuhkan untuk jadi analis kredit level apa itu adalah ini, ini, ini. Tim kurikulum D IV Perbankan menerjemahkan skill tersebut ke dalam matakuliah ini, ini, dan ini, seperti itu. Kalo soal mata kuliah kami yang lebih tahu oh ada matakuliah ini, ada matakuliah ini. Kalo butuh matakuliah baru kita buatkan. Bahkan kalo belum ada SDM nya, ya kita training kan nanti dosennya.'

Berikut adalah contoh standarisasi kompetensi pada Program Studi Perbankan

Profile lulusan: Wealth Management

Sertifikasi: Certified Wealth Manager

Di bawahnya itu ada Certified Financial Planner sebenarnya dua-duanya itu pekerjaannya hampir mirip ya mengurus mengelola kekayaan orang. Di perbankan juga ada seperti itu ada sertifikasinya, diarahkan lulusan kami itu jadi Wealth Management Officer, sertifikasinya kalo memang ybs punya uang lebih ya pilihah yang $C W M$, tapi kalo ngak begitu punya uang, ya pilih yang CFP.

Namun demikian, informan menekankan bahwa proses standarisasi yang menekankan pada kompetensi, skill kerja tidak boleh menjadi alasan bahwa kehidupan akademik di kampus menjadi hilang. Hal ini dilandasi alasan bahwa tidak diperlukan perkuliahan untuk memperoleh kompetensi, keahlian kerja karena kemampuan tersebut dapat diperoleh oleh peserta melalui kursus jangka pendek (short course).

"Issue seperti the death of university, kampus, tidak laku lagi karena yang lebih ditekankan adalah kompetensi, skill kerja, jadi ngapain lagi ke kampus, langsung aja training di mana, ambil aja modul2 dari internet."

Di sisi lain, informan juga memberikan masukan bahwa standarisasi kompetensi membutuhkan biaya yang cukup besar sehingga 
perlu dipikirkan kemampuan finansial calon peserta dan kecakapan kampus dalam melakukan negosiasi dengan pihak industri yang diwakili oleh LSPP untuk meringkan biaya sertfikasi kompetensi

"Bisnis mereka (lembaga sertifikasi kompetensi) adalah meningkatkan kompetensi, jadi itu tidak akan buat masalah bagi saya kalo memang tidak dimasukkan dalam pendidikan, maksudnya pendidikan di perguruan tinggi, memang ngak masalah kan bisa jadi orang-orang yang sudah sarjana karena mereka mensyarakatkan harus sudah sarjana, jadi yang sudah sarjana mereka ambil sertifikasi kompetensi untuk meningkatkan kompetensi mereka. Jadi saya kira sah-sah saja kalo seperti itu. Tapi begitu perguruan tinggi akan mengarah ke sertifikasi kompetensi, ada baiknya kan perguruan tinggi bisa nego, karena kalo tidak, itu akan dibilang kuliah kok seperti training saja untuk lulus sertifikasi, kita kan nggak seperti itu. Kita lah yang mengembangkan ilmu memang. Jadi unsur-unsurnya harus dimasukkan, jadi ngak bisa kurikulum plek sama banget dengan sertifikasinya. Justru kami nanti dengan bekal yang lebih kaya, sertifikasi itu seperti ujian kemampuan dasar."

\section{Standar Kompetensi Ahli Akuntansi Sektor Publik}

Standar akuntansi pemerintahan atau SAP adalah prinsip-prinsip akuntansi yang diterapkan dalam menyusun dan menyajikan Laporan Keuangan Pemerintah. Laporan tersebut secara garis besar terbagi menjadi Laporan Keuangan Pemerintah Pusat (LKPP) dan Laporan Keuangan Pemerintah Daerah (LKPD). Standarisasi ini dilakukan dalam rangka transparansi dan akuntabilitas penyelenggaraan akuntansi pemerintahan. Standar Akuntansi Pemerintah dinyatakan dalam Pernyataan Standar Akuntansi Pemerintahan (PSAP). PSAP ini dibarengi dengan Interpretasi Pernyataan Standar Akuntansi Pemerintahan (IPSAP) atau Buletin Teknis SAP. Gunanya adalah untuk menghindari salah arti dalam penggunaan PSAP dan mengatasi permasalahan teknis yang mungkin akan terjadi. IPSAP dan Buletin
Teknis SAP disusun dan diterbitkan oleh Komite Standar Akuntansi Pemerintahan (KSAP) dan diberitahukan kepada Pemerintah dan Badan untuk memberikan peningkatan kualitas dari LKPP dan LKPD.

Sistem Akuntansi Pemerintahan adalah serangkaian prosedur manual maupun yang terkomputerisasi mulai dari pengumpulan data, pencatatan, pengikhtisaran dan pelaporan posisi keuangan dan operasi keuangan pemerintah (Peraturan Pemerintahan tentang Standar Akuntansi Pemerintahan, pasal 1). Berikut usulan isi materi standarisasi kompetensi yang muncul dalam focus group discussion dengan para ahli akuntansi pemerintah di Direktorat Jenderal Perbendaharaan tersebut.

a. Standarisasi Mahasiswa Program Studi Diploma 3

1) Standar Akuntansi Pemerintahan (SAP)

Materi yang diajarkan dalam perkuliahan kepada mahasiswa dan yang diujikan dalam standarisasi kompetensi adalah SAP yang bersifat regulation based, yaitu SAP yang diterbitkan dikarenakan menyesuaikan dengan aturan perundang-undangan. SAP tersebut antara lain SAP tentang Penyajian Laporan Keuangan (termasuk SAP tentang LRA, LAK, dan CaLK), SAP tentang Aset Tetap, Persediaan, Investasi, Konstruksi Dalam Pengerjaan, dan Badan Layanan Umum, serta buletin teknis yang terkait dengan hal tersebut, antara lain Buletin Teknis Penyusutan, Piutang, Aset Tidak Berwujud.

2) Sistem Akuntansi Pemerintahan

Materi yang diajarkan dalam kuliah dan menjadi materi ujian adalah aplikasi Sistem Akuntansi Instansi Berbasis Akrual (SAIBA) dan Sistem Aplikasi Keuangan Tingkat Instansi (SAKTI) serta peraturan tentang Sistem Akuntansi Pemerintah Pusat. Pada tahap uji standarisasi kompetensi aplikasi, maka diperlukan simulasi transaksi-transaki yang mencakup semua transaksi dalam modul-modul aplikasi tersebut. Sistem Aplikasi Keuangan Tingkat Instansi (SAKTI) adalah aplikasi yang digunakan sebagai sarana bagi satker dalam mendukung implementasi SPAN untuk melakukan pengelolaan keuangan yang meliputi tahapan perencanaan hingga pertanggungjawaban anggaran. SAKTI mengintegrasikan seluruh aplikasi satker yang 
ada. Aplikasi SAKTI mempunyai fungsi utama mulai dari Perencanaan, Pelaksanaan hingga Pertanggungjawaban Anggaran. Selain itu, SAKTI juga telah menerapkan konsep single database. Aplikasi SAKTI digunakan oleh entitas akuntansi dan entitas pelaporan Kementerian Negara/Lembaga. Seluruh Transaksi entitas akuntansi dan entitas pelaporan dilakukan secara sistem elektronik. SAKTI terdiri atas SAKTI online dan SAKTI offline, yang menggunakan sistem single entry point, single database, dan akuntansi berbasis akrual. Adapun periodisasi transaksi dalam SAKTI meliputi Januari sampai dengan Desember, unaudited, dan audit.

SAKTI mencakup seluruh proses pengelolaan keuangan negara pada SATKER dimulai dari proses Penganggaran, Pelaksanaan, sampai dengan Pelaporan. Masing-masing proses pengelolaan keuangan diperankan oleh modul-modul aplikasi sebagai berikut :

1. Proses penganggaran diperankan oleh modul Penganggaran.

2. Proses pelaksanaan diperankan oleh beberapa modul, yaitu modul Komitmen (meliputi sub-modul Manajemen Supplier dan sub-modul Manajemen Komitmen), modul Bendahara, modul Aset Tetap, modul Persediaan, dan modul Pembayaran.

3. Proses pelaporan diperankan oleh modul GL dan Pelaporan.

Dengan demikian, rincian berbagai modul yang ada di SAKTI terdiri dari Modul Penganggaran, Modul Komitmen, Modul Pembayaran, Modul Bendahara, Modul Persediaan, Modul Aset Tetap, Modul Pelaporan dan Modul Administrator.

Aplikasi SAIBA merupakan aplikasi yang dihasilkan dari pengembangan Sistem Akuntansi Instansi (SAI). SAIBA merupakan terobosan aplikasi akuntansi berbasis akrual yang diharapkan memenuhi kebutuhan informasi laporan keuangan yang disyaratkan dalam SAP. Mengingat bahwa aplikasi SAIBA adalah sebuah sistem akuntansi berbasis sistem informasi, maka pengelolaan sistem informasi secara efektif dan efsien di dalam Kementerian Negara/Lembaga menjadi sebuah hal yang sangat penting. Sebenarnya, SAIBA merupakan aplikasi masa transisi sebelum aplikasi SAKTI diterapkan di seluruh Kementerian/Lembaga Pemerintah Pusat.

b. Standarisasi Mahasiswa Program Studi Strata 1 atau Diploma IV Akuntansi

1) Standar Akuntansi Pemerintahan (SAP)

Materi yang diajarkan dalam perkuliahan kepada mahasiswa dan yang diujikan dalam standarisasi kompetensi adalah SAP yang bersifat principle based, yaitu SAP yang diterbitkan untuk memenuhi prinsip-prinsip dasar dalam akuntansi pemerintahan dan sesuai dengan International Public Sector Accounting Standards (IPSAS). SAP yang termasuk dalam principle based tersebut adalah yang mengatur tentang prinsip-prinsip pendapatan, belanja, beban, dan lainnya.

2) Sistem Akuntansi Pemerintahan

Direktorat APK tidak terlalu menekankan materi Sistem Akuntansi yang sebaiknya disampaikan kepada mahasiswa program studi Strata 1 atau Diploma 4 dan diujikan dalam standarisasi kompetensi. Namun apabila materi Aplikasi SAKTI dan SAIBA diujikan dalam standarisasi kompetensi, sebaiknya lebih mendalam dan lebih rinci daripada yang diujikan kepada mahasiswa Diploma 3. Dalam FGD dengan Direktorat APK Ditjen Perbendaharaan tersebut tidak membahas materi yang berkaitan dengan Konsep Multy Entry Multy Exit (MEME), Sistem Informasi Manajemen Akuntansi Barang Milik Negara (SIMAK-BMN). Namun dalam diskusi juga disinggung tentang Kurikulum Akuntansi Pemerintahan.

Learning Outcome yang ingin diraih dari proses Standarisasi Kompetensi Akuntansi Sektor Publik adalah akuntan sektor publik yang berkarya sebagai in house akuntan mampu menerapkan :

1. Kompetensi Akuntansi Pemerintahan pada Kementerian Lembaga SAIBA
a) Menerapkan
Siklus
Akuntansi
Pemerintahan
- Standar akuntansi pemerintahan dan kebijakan akuntansi
- Sistem Akuntansi
- Proses dan laporan keuangan sistem akuntansi instansi
b) Menerapkan Proses Akuntansi dan Aplikasi
- Saldo awal 
- Transaksi DIPA dan revisi DIPA Transaksi periode berjalan;

- Transaksi pendapatan

- Transaksi belanja

- Transaksi Uang Persediaan

- Transaksi pengembalian pendapatan

- Transaksi pengembalian belanja

- Transaksi hibah langsung bentuk uang/jasa, dan

- Transaksi pengembalian hibah langsung.

c) Menerapkan Transaksi Aset

- Transaksi Piutang

- Transaksi Persediaan

- Transaksi Aset Tetap/Lainnya

- Kas di Bendahara Pengeluaran

- Transaksi Transfer Masuk/Transfer Keluar non Persediaan/BMN

d) Mendemosntrasikan Penyesuaian dan Koreksi;

- Penyesuaian

- Koreksi beban asset, koreksi lainnya, koreksi antarbeban

e) Mendemosntrasikan Penyusunan Laporan Keuangan

- Laporan Realisasi Anggaran

- Neraca

- Laporan Operasional

- Laporan Perubahan Ekuitas

- Catatan atas Laporan Keuangan

2. Sertifikasi Akuntansi Kementerian Lembaga Persediaan dan SIMAK BMN

1. Menerapkan levelisasi golongan BMN

2. Menerapkan Penggunaan Menu Transaksi Aplikasi Persediaan

- Transaksi Persediaan Masuk

- Transaksi Persediaan Keluar

- Transaksi Koreksi

- Transaksi hasil Opname Fisik

- Transaksi Penghapusan Usang/Rusak

3. Menerapkan Petunjuk Teknis Penggunaan Menu Transaksi Aplikasi SIMAK-BMN

a) Transaksi BMN

1) Saldo Awal

2) Perolehan BMN

3) Perubahan BMN

4) Inventarisasi dan Penilaian Kembali
5) Penghapusan BMN

6) BPYBDS

7) Perolehan ATR (Menambah Masa Manfaat)

8) Usulan Barang Hilang, Rusak Berat dan Hibah DK/TP

9) Kemitraan Dengan Pihak keTiga

10) BMN Bersejarah dan Barang Pihak Ketiga

b) Transaksi Konstruksi Dalam Pengerjaan (KDP)

3. Standarisasi Kompetensi Teori dan Kasus Akuntansi Pemerintah

1. Menjelaskan laporan keuangan pemerintah dan mempraktikkan proses akuntansi pemerintah

2. Menjelaskan laporan keuangan pemerintah dan mempraktikkan proses akuntansi pemerintah

3. Mempraktikkan transaksi Aset Tetap dan Persediaan yang terjadi di pemerintah

4. Mempraktikkan transaksi KDP yang terjadi di pemerintah

5. Mempraktikkan transaksi Investasi yang terjadi di pemerintah

6. Mempraktikkan proses penyusutan AT yang terjadi di pemerintah

7. Mempraktikkan transaksi Piutang dan ATB yang terjadi di pemerintah

8. Menjelaskan SAPP pemerintah

9. Mempraktikkan transaksi SAIBA yang terjadi di pemerintah

10. Mempraktikkan transaksi SAIBA yang terjadi di pemerintah

11. Mempraktikkan SIMAK BMN yang terjadi di pemerintah

12. Mempraktikkan transaksi SIMAK BMN yang terjadi di pemerintah

13. Mempraktikkan Aplikasi SAKTI yang terjadi di pemerintah

14. Mempraktikkan Aplikasi SAKTI yang terjadi di pemerintah

15. Menjelaskan secara mendalam mengenai akuntansi pendapatan pemerintah

16. Memecahkan masalah dan memberikan solusi mengenai kasus yang diberikan

17. Menjelaskan secara mendalam mengenai akuntansi belanja dan beban 
18. Memecahkan masalah dan memberikan solusi mengenai kasus yang diberikan

19. Menjelaskan secara mendalam mengenai akuntansi pembiayaan

20. Memecahkan masalah dan memberikan solusi mengenai kasus yang diberikan

21. Memecahkan masalah dan memberikan solusi mengenai kasus yang diberikan

22. Menjelaskan SAPP pemerintah

23. Menjelaskan KABA secara baik

24. Mempraktikkan Aplikasi SAKTI yang terjadi di pemerintah

25. Mempraktikkan Aplikasi SAKTI yang terjadi di pemerintah

26. Mempraktikkan Aplikasi SAKTI yang terjadi di pemerintah

27. Mempraktikkan AplikasiSAIBA yang terjadi di pemerintah

28. Mempraktikkan Aplikasi SIMAK BMN yang terjadi di pemerintah

\section{SIMPULAN DAN SARAN}

Penguasaan kompetensi keahlian akuntansi sektor publik merupakan sebuah keharusan yang telah ditetapkan oleh regulasi maupun karena factor perkembangan teknologi informasi. Seorang ahli madya akuntansi sektor publik harus memiliki kompetensi untuk mengaplikasikan SAKTI dan penerapan standar akuntansi sektor publik dengan pendekatan rules base. Untuk tingkat sarjana termasuk juga sarjana terapan harus mampu mengoperasikan aplikasi SAKTI dan penerapan standar akuntansi sektor publik dengan pendekatan principles base.

\section{UCAPAN TERIMA KASIH}

Tim peneliti mengucapkan terima kasih kepada Politeknik Keuangan Negara STAN yang telah membantu dalam bentuk arah kebijakan riset dan dukungan pendanaan. Tim Peneliti mengucapkan terima kasih kepada Sekolah Vokasi Universitas Gajah Mada, Universitas Brawijaya, Politeknik Negeri Bandung, Politeknik Negeri Malang dan Direktorat Jenderal Perbendaharaan Kementerian Keuangan yang telah bersedia bertukar pengetahuan dan menjadi sumber informasi dalam penelitian ini.

\section{DAFTAR PUSTAKA}

Astutin, S. (2008). Peran Teknologi Komputer Terhadap Profesi Akuntan Dalam Sistem Informasi Akuntansi di Era Globalisasi. Jurnal Akuntansi FE Unsil, 488-493.

Flecther, S. (2005). Competence-based Assessment Techniques. London: Kogan Page.

Kusumaningrum, D., \& Kirowati, D. (2017). Faktor - Faktor yang Mempengaruhi Persepsi Mahasiswa Akuntansi untuk Memperoleh Gelar Sertifikasi Profesi Akuntansi. Jurnal Akuntansi dan Sistem Informasi, 56-64.

Sanberg, J. (2000). Understanding Human Competence At Work : An Interperative Approach. Academy of Management Journal , 1-14.

Simanjuntak, B. L. (2005). Menyongsong Era Baru Akuntansi Pemerintahan di Indonesia. Jurnal Akuntansi Pemerintahan Vol.1 .

Spencer, Jr, L. M., \& Spencer, S. M. (1993). Competence at Work : Models for Superior Performance. Canada: John Wiley and Sons.

Sugiyono, S. (2017). Metode Penelitian Keuantitatif, Kualitatif dan $R \& D$. Bandung : Alfabeta.

Taufik, M. (2017). Pengaruh Teknologi Informasi Dalam Keprofesian dan Implikasinya Dalam Dunia Pendidikan. Jurnal Kajian Penelitian Pendidikan dan Pembelajaran, 176-185.

Widarno, B. (2007). Profil dan Kompetensi Sarjana Akuntansi. Jurnal Ekonomi dan Kewirausahaan, 150-159.

Wikansari, R., Sutjiatmo, B. P., \& Kurniawan, M. S. (2018). Kepuasan Akademik, Konsep Diri Vokasional, dan Efikasi Diri Akademik Pada Mahasiswa Sekolah Vokasi Dalam Menghadapi Era Disrupsi Teknologi. Seminar Nasional Pakar (pp. 197 - 206). Jakarta: Trisakti University.

Young, M. (2011). What Are Schools For? Educacao, Sociedade and Culturas, 145 - 155. 
Yuliawati. (2019, Juli 15). katadata.co.id. Retrieved from katadata.co.id: https://katadata.co.id/berita/2019/07/15/ pidato-lengkap-lima-visi-presidenterpilih-2019-2024-jokowi

Undang-Undang No 12 Tahun 2012 Tentang Pendidikan Tinggi. (2012). Republik Indonesia.

Peraturan Presiden No 18 Tahun 2012 tentang Kerangka Kualifikasi Nasional Indonesia . (2012). Republik Indonesia.

Peraturan Menteri Pendidikan dan Kebudayaan No 83 Tahun 2013 tentang Sertifikasi Kompetensi. Republik Indonesia.

Peraturan Menteri Riset, Teknologi dan Pendidikan Tinggi No 44 Tahun 2015 Tentang Sertifikasi Kompetensi. (2015). Republik Indonesia. 